\title{
Supply chain analysis of import fresh fruit business in Thailand using the supply chain operations reference (scor) model
}

\author{
Thanapong Ruamsuke ${ }^{1}$, and Pornthipa Ongkunaruk ${ }^{2 *}$ \\ ${ }^{1}$ Department of Logistics Technology, Faculty of Social Technology, Rajamangala University of \\ Technology Tawan-ok, Pluang, Khao Khitchakut, Chanthaburi 22210, Thailand \\ ${ }^{2}$ Department of Agro-Industrial Technology, Faculty of Agro-Industry, Kasetsart University, \\ Ngam Wong Wan Rd. Lad Yao, Chatuchak, Bangkok 10900, Thailand
}

\begin{abstract}
According to the increasing trend of online shopping through social media and reduced international trade barriers and tariffs, there is an opportunity for entrepreneurs to import fresh fruit. However, operations throughout the supply chain have suffered from product quality control and cold chain management. The research aimed to analyze the supply chain of import chilled fresh fruit based on the Supply Chain Operations Reference (SCOR) Model and suggest optimising cold chain management. The data are collected from case study executives and operators using in-depth interviews and observation. The main problems are price markdown due to the overestimation of slow-moving products and food loss and low productivity, no standard operations in receiving and distribution, and lack of proper metrics to measure the supply chain performance. Finally, the suggestions of improvement include establish demand planning and forecasting, implement supply chain optimization and inventory monitoring, develop a lot tracking system, standard operating procedures for receiving process, enhance worker efficiency, use the sensor with the Internet of Things (IoT) solution, implement supply chain risk monitoring, and online marketing. In summary, this research will be useful for other traders to reduce food loss throughout the supply chain.
\end{abstract}

\section{Introduction}

The epidemic situation of Covid-19 directly affects consumer behavior and expedites the growth of e-commerce. Manufacturers and merchants face new challenges such as delivery times, storage, and quality control during distribution, including lockdown measures. This leads to a slower process while the demand for products is still ongoing [1]. For fruits and vegetables, post-harvest management is crucial to maintain quality. The process begins with the harvesting of horticultural produce while they partially ripen or ripen. Post-harvest fruits and vegetables have been developed to get a tender and soft texture, high humidity, and water activity. Besides, transpiration or water loss and respiration affect heat in

*Corresponding author: pornthipa.o@ku.ac.th 
produce. Fresh produce quality assessment consisted of measurement of appearance, texture, taste, nutrition, food safety, product physiology, and other factors such as plant diseases and insects, pests, mechanical injury, and contamination after harvest [2]. FAO describes that food loss refers to food that was dropped, rotten, lost, or deteriorates its values and quality from the production process, post-harvest, processing, and distribution in the food supply chain. While food waste happens in the retail stores and consumers. Surprisingly, the quantification of food loss and waste is approximately $30 \%$ of the global production [3], while in developing countries, including Thailand, it accounts for $44 \%$ of the world's food loss [4]. In Thailand, various causes of food loss and food waste are identified such as high temperature which particularly caused food spoiling microorganisms to grow rapidly in food. Without control of food in suitable conditions throughout the food supply chain, it will result in food loss.

The case study is a leading company in the fresh fruit import and export business in Thailand with continuous growth in sales volumes. The company composes of two parties. First, the fresh fruit packing house located in Eastern and Southern Thailand collects domestic fruits for export. Second, the cold storage warehouse located in Pathum Thani province operates for the import products. The cold storage warehouses keep fresh fruits imported from abroad such as oranges, cherries, apples, grapes, and strawberries. The main import sources are Australia, Japan, Chile, New Zealand, China, Vietnam, South Korea, and the United States. The customers consist of wholesale markets, hypermarkets, food service providers, and hotels. The objectives of this study are to analyze the business processes of the case study, identify the current problems, and suggest how to improve business efficiency to enhance customer service. This study is focused on the fruit import supply chain because it has a high risk of loss from tropical conditions and lacks proper cold chain management.

\section{Literature review}

The cold chain management subjects to well establish the design and management of the post-production of temperature-sensitive commodities and perishable goods that have been designed specifically for this product in environments with air conditioning as the proper temperatures and humidity to guarantee product safety, maintain the quality and value, and maximize trade potential [5]. Supply chain management means controlling supply chain activities, including the relationships of related organizations from upstream to the downstream, which looks like a chain to achieve efficiency throughout the production process to the consumer. The supply chain operation reference model (SCOR Model) is generated by the supply chain council to refer to a model of operational processes in the supply chain by combining the business processes, metrics, practices, people, and special applications $[6,7]$. Furthermore, work processes are set to the same standard, divided into 6 processes: (1) Plan is the process of balancing requirements and resources throughout the supply chain. It involves the combination of requirements, collecting of information on available resources, matching demands and supplies to determine planned abilities and gaps in demand or resources, and identify procedures to correct these gaps. (2) Source is the process of procuring raw materials, inbound logistics scheduling, receiving, validation, confirmation, storage, and the invoice accepting from the suppliers. (3) Make is the process of transforming materials to completed products or generating the content for services related to manufacturing, maintenance, replacement, recycling, refurbishment, and restoration. (4) Deliver is the process of delivering related to the receipt, validation, order fulfillment, packing, shipping, delivery, and customer service involved delivery and customer invoicing. (5) Return is the process of goods reverse flow related to the connecting of the needs to return, the disposition decision making, the scheduling of the 
return, and the freight and receiving of the returned goods. (6) Enable is the process of supply chain management regarding business rules, organization, performance measurement system, the management of data, resources, facilities, contract and risk.

This framework has four levels as follows. First, level 1 includes the scope of supply chain stakeholders and their major processes classified into five types: plan, source, make, deliver and return. Second, level 2 includes the configuration of process categories such as make to stock, make to order, and engineer to order. A supply chain is visualized by key process categories. Third, level 3 includes process activities that divide processes into process elements, inbound and outbound processes, process performance measurement, and best practices. Finally, level 4 includes improvement activities that implement unique SCM practices to the organizations [8].

The supply chain process reference model has been used in many case studies [9] starting with enhancing business competitiveness such as ready-made garments for small and mid-size enterprises [10], printing and merchandising Services [6], developing operational processes which expanding marketing margins in hydroponic vegetable supply chain and risk management system in frozen tuna products [11], and halal slaughterhouses [12]. It is also used to develop a model for supply chain management, such as the cold chain model of deep-frozen pizza delivery [5], the critical elements of import and export procedures with customs supply chain [13], green supply chain to manage domestic industry waste resource [14] and the performance measurement model for retail service by using the halal SCOR model [15]. Moreover, it has been used to develop the interoperability of strategic alignment between business, IT strategies, and performance measures in developing a sustainable procurement monitoring system [16] and improvement of palm oil supply chain best practice through analysis software [7].

\section{Methodology}

First, an in-depth interview with the case study manager by using the semi-structured interview method by defining a topic about import procedure, supply chain management, and performance evaluation $[11,12]$ was performed. Then, the observation of their operations and analysis of the staff's operating procedures from receiving, storing, and delivering to the wholesaler and department store $[10,16]$ were implemented. Next, stakeholders in the import of fresh fruit supply chain were analyzed i.e. farmer, packing house, exporter, freight forwarder, importer, wholesaler, department store, and retailer. The importer has a role in sorting and keeping quality products and distributing them to a downstream supply chain. Then, the supply chain process reference model (SCOR Model) version $12[6,16]$ was used to analyze and enhance the supply chain management process. The scope of the study focused on importing fruits activities from abroad to distributing to the destination market.

\section{Result and discussion}

\subsection{The fresh fruit supply chain stakeholders}

The fresh fruit supply chain is a complex network with related stakeholders as presented in Fig. 1 and Table 1. 


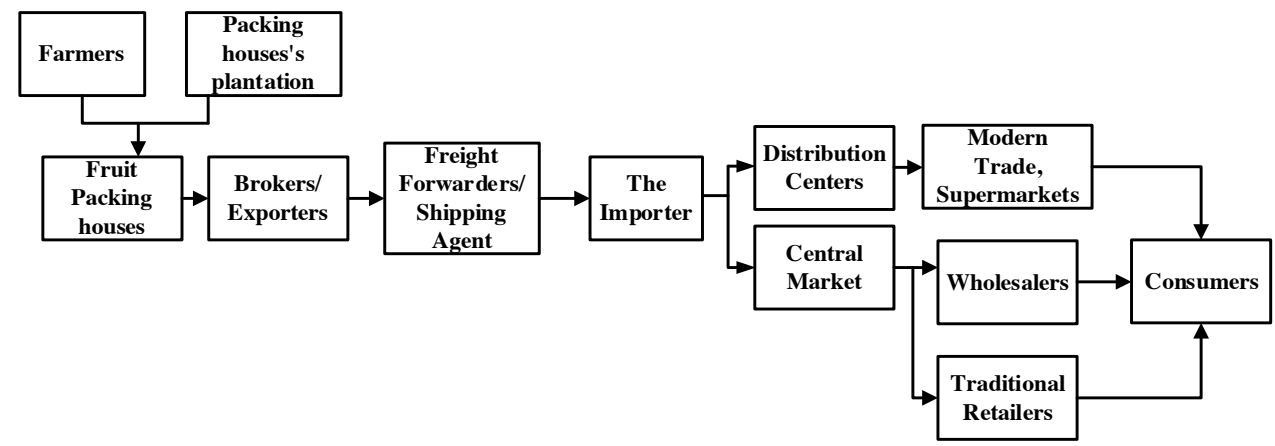

Fig. 1. The import fresh fruit supply chain

Table 1. Role of a related person in the supply chain.

\begin{tabular}{|c|c|}
\hline Stakeholders & Logistics Activities \\
\hline 1. Farmers & $\begin{array}{l}\text { They are responsible for cultivating, harvesting, and delivering fruit to the packing } \\
\text { house. There are } 3 \text { types of farmers as follows: 1) An individual farmer who owns } \\
\text { land 2) A group of farmers or cooperatives which have contracts and open auctions } \\
\text { with the customer, and 3) The farmers from farms belong to the packing house. }\end{array}$ \\
\hline $\begin{array}{l}\text { 2. Packing } \\
\text { houses }\end{array}$ & $\begin{array}{l}\text { They are responsible for collect fruits from their garden or buy from other farmers or } \\
\text { groups of farmers. The operations include cleaning, sorting, coating, packing, and } \\
\text { storing fresh produce in temperature-controlled conditions. There are two groups i.e. } \\
\text { 1) A subsidiary packing house of an export company 2) Others packing house } \\
\text { companies }\end{array}$ \\
\hline $\begin{array}{l}\text { 3. Exporters } \\
\text { and Brokers }\end{array}$ & $\begin{array}{l}\text { They are responsible for procuring fresh fruits and vegetables from the packing } \\
\text { house and export to the destination market. In negotiations with importers, there are } \\
\text { both sales contracts and non-sales contracts. The exporters will take pictures of the } \\
\text { actual products and send them to the importer to certify products before delivery. } \\
\text { Next, they contact the freight forwarders to transport goods to the destination } \\
\text { country. }\end{array}$ \\
\hline $\begin{array}{l}\text { 4. Freight } \\
\text { forwarders and } \\
\text { shipping } \\
\text { companies }\end{array}$ & $\begin{array}{l}\text { They are in charge of international freight and customs clearance from the country } \\
\text { of origin. Most are employed by exporting companies according to incoterms. There } \\
\text { are three main modes of transportation. First, the air freight imports cherry from } \\
\text { New Zealand and strawberries from Japan. The delivery time is short but high price. } \\
\text { Second, the sea freight imports apples from the USA, grapes from Australia. Third, } \\
\text { the road mode imports apples from China. }\end{array}$ \\
\hline $\begin{array}{l}\text { 5. The case } \\
\text { study company }\end{array}$ & $\begin{array}{l}\text { It performs two major functions as 1) Inbound logistics with exporters, including } \\
\text { import planning, negotiating on quantity, price, quality, and purchasing 2) Domestic } \\
\text { operations and outbound logistics include the inbound customs clearance, cold } \\
\text { storage, negotiation, and sales promotion, receive orders, and domestic } \\
\text { transportation. }\end{array}$ \\
\hline $\begin{array}{l}\text { 6. Wholesalers/ } \\
\text { Distribution } \\
\text { Centers }\end{array}$ & $\begin{array}{l}\text { There are two major first-tier customers of the case study company. 1) Wholesalers } \\
\text { are the major customers accounting for } 60-70 \% \text {. They operate purchasing, selecting, } \\
\text { and reselling products to retailers located in the Talaad Thai market. In general, they } \\
\text { do not control the temperature and hygiene in storage and transportation systems. 2) } \\
\text { Distribution center of the modern trades such as hypermarkets. Their purchasing } \\
\text { plans will be shared with the importer and they use their temperature-controlled and } \\
\text { hygienic distribution system. }\end{array}$ \\
\hline 7. Talaad Thai & $\begin{array}{l}\text { It is the largest central market in Thailand where sellers and buyers meet, bid, and } \\
\text { negotiate for agricultural products. }\end{array}$ \\
\hline 8. Retailers & $\begin{array}{l}\text { The retailers are 1) Modern trades and supermarkets that receive products from their } \\
\text { distribution centers. 2) Traditional trades and foodservice providers who purchase } \\
\text { and pick up products directly from wholesalers to resell in their stores. Most } \\
\text { traditional stores are non-temperature-controlled. }\end{array}$ \\
\hline 9. Consumers & Consumers may buy products at the retail stores or order online for home delivery \\
\hline
\end{tabular}




\subsection{SCOR Model Level 1 of the import fresh fruit supply chain}

From the import fresh fruit supply chain analysis using SCOR Model level 1, there are six processes as Fig. 2.

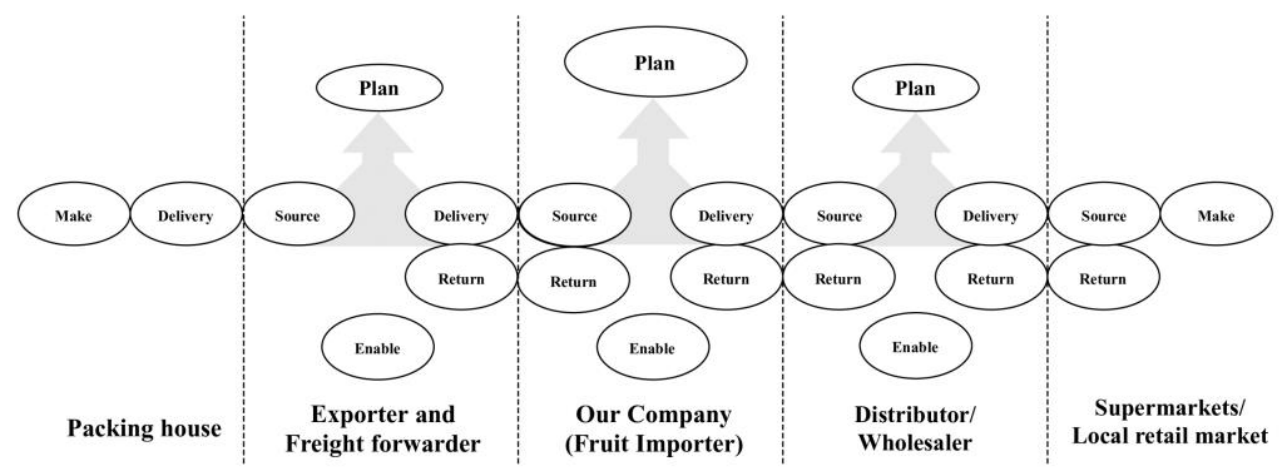

Fig. 2. SCOR Model Level 1: the scope of the import fresh fruit supply chain.

The main products are fresh fruits such as cherries, apples, citrus, grapes, and mushrooms sourced from all over the world to have products available throughout the year. China is the main source of imported fruits of the company and the important partner in supplying and distributing products. Activities in supply chain management are as follows:

\subsubsection{Plan}

The importer received the supply planning from the exporters. Then, the sourcing plan is estimated based on future market demand. The importer plans to procure based on the type of products, grade, quantity, and sources of production. The sales contract does not specify detail but relies on the details of a shipment's purchasing order for flexibility. There are two distribution channels. First, wholesaler and local market where the importer did not have a long-term plan and contracts but used the negotiation based on the situation. Second, supermarkets where the contracts are signed and the order is based on the volume of goods sold.

\subsubsection{Source}

The importer coordinated with exporters and export brokers to procure fresh fruits from the packing house, agricultural co-operative, and farmer groups in two cases: pre-order and urgent order. The importer has quality control representatives in the export country to inspect the product at packing houses. The quality assessment criteria including size, weight, color, and photography returned to the purchasing department. International shipping is responsible for delivery and customs clearance from the country of origin. When the reefer containers arrive at the cold storage, warehouse staff randomly inspect the quality of the products before receiving and storing them.

\subsubsection{Make}

The importer had no production process. However, the importer assured that the production at farms and packing houses follows standard practices such as good agriculture practices (GAP) and Good Manufacturing Practices. 


\subsubsection{Deliver}

Outbound logistics related to distribution to customers. First, delivery to wholesalers or traditional trade in the central markets transports by regular pickup trucks. Second, delivery to distribution centers of the modern trade uses temperature-controlled vehicles.

\subsubsection{Return}

Defective products will be rejected and feedback the quality problem to suppliers. The importer will send pictures to the exporter. The rejected products will be returned to the suppliers or bought at a lower price.

\subsubsection{Enable}

Management of the importing process consisted of six processes are 1) Business rules management in customs clearance which requires product certification criteria from the country of origin and hygienic standards for storing products in the cold room. 2) Performance management on product quality inspection at cold storage and distribution to customers 3) Human resource management identifies duties and selects the qualified employees. 4) Asset management controls and maintains resources to be ready for operation such as refrigeration systems in cold storage and vehicles. 5) Contract and agreement management is adjusted to satisfy suppliers and customers. 6) Risk management assesses operational risks, including internal factors such as domestic market demand and external factors such as exchange rates, the number of goods and quality of origin, and import regulations to adjust the operation policy accordingly.

\subsection{SCOR Model Level 2 Import fresh fruit supply chain Configuration}

At SCOR model level 2, the operating process analysis was presented as shown in Fig. 3 and the geographical mapping of the distribution in Fig. 4. There are two main sourcing types of the importer. First, source stocked product $(\mathrm{sS} 1)$, the importer procures the stable demand products such as apples from China and stores them in a temperature-controlled system. Then, the delivery process is deliver stocked product (sD1), for example, apples from China taking 4-5 days of road transportation. Second, source make to order product (sS2), the importer procures the fast-moving products such as cherry from Chile and New Zealand. Therefore, the delivery process chosen is deliver make to order product (sD2).

Moreover, we analyzed the current situations using the SCOR model diagram (As-Is), as follows:

1) Plan supply chain (sP1): The importer has no supply chain plan. Hence, they should establish a supply chain plan in the future.

2) Plan source (sP2): The importer plans the purchasing of products based on historical information, the supply capacity and capacity of the exporter, and the current market trends to determine the type, quality, source, and price.

3) Plan deliver (sP4): The importer plans shipments based on customer requirements, including product type, quantity, time, delivery mode, and temperature-controlled vehicles. While a delivery plan considers the mode of delivery related to the product cost and the urgency of demand.

4) Source stocked product $(\mathrm{sS} 1)$ : The importers purchase fruits with consistent yearround demand and long shelf life, such as apples and grapes, by ordering in advance. When the products arrive at the port, the company has the trucks to pick up them to keep in the cold room. 
5) Deliver stocked product (sD1): Delivery of stock products to customers based on their order.

6) Source make to order product ( $\mathrm{sS} 2)$ : The importer has expedited procurement according to the needs of customers such as early seasons, produced only in a certain area, and high-priced categories. As a result, purchased and imported items are not stored in the warehouse for a long time.

7) Deliver make to order product (sD2): Delivery of fast-moving products has specific requirements such as time window, product and service quality, and product warranty.

8) Source return defective product (sSR1): The assessment of the product returned is based on the agreement. In the case that there is a quality inspection agent in the origin country, the importer will not claim and return the product to the exporter. However, if there is no agent, there will be negotiation with the exporter to return or buy them at a lower price. The exporter will sell these products to other buyers at a lower price.

9) Deliver return defective product (sDR1): If the customers found defective products, then they will be considered if they can buy at a lower price or return if they are not willing to buy at a lower price. The importer will sell these products to other buyers because there is no sorting process at the warehouse.

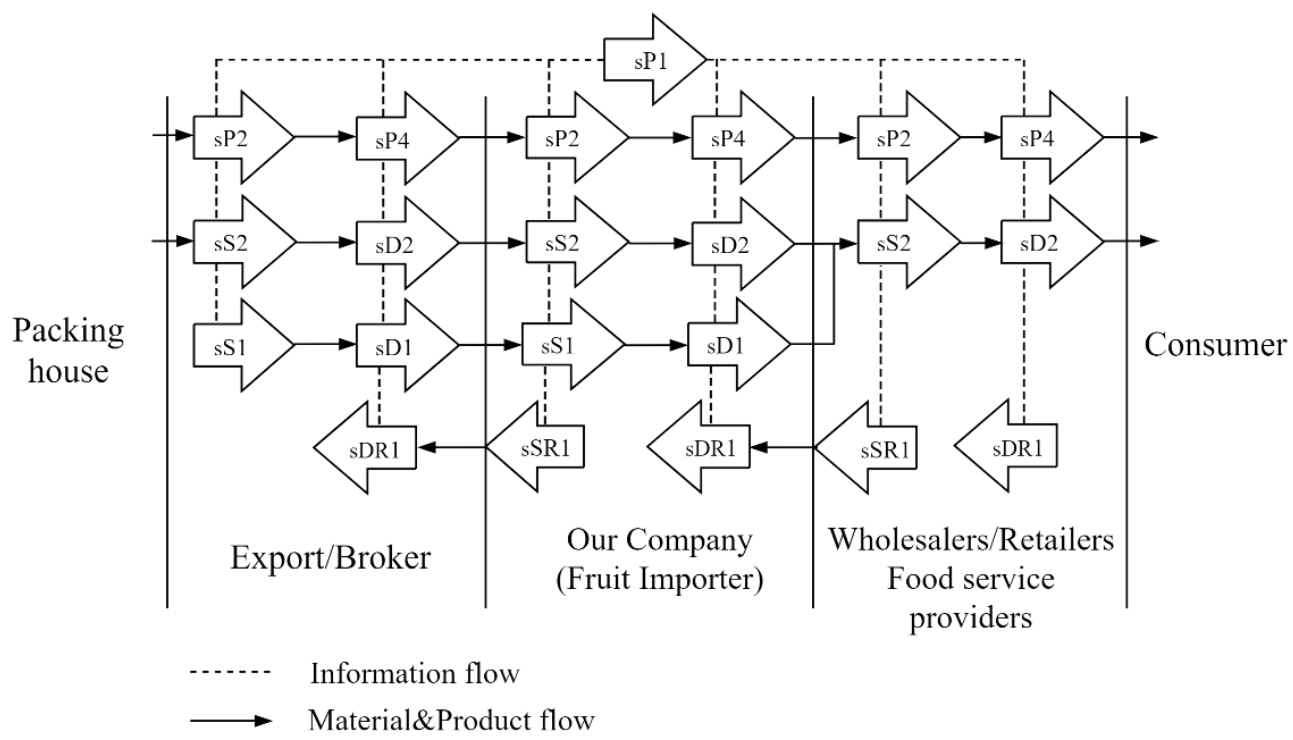

Fig. 3. SCOR Model level 2 Configuration Level of the import fresh fruit supply chain (As-Is) 


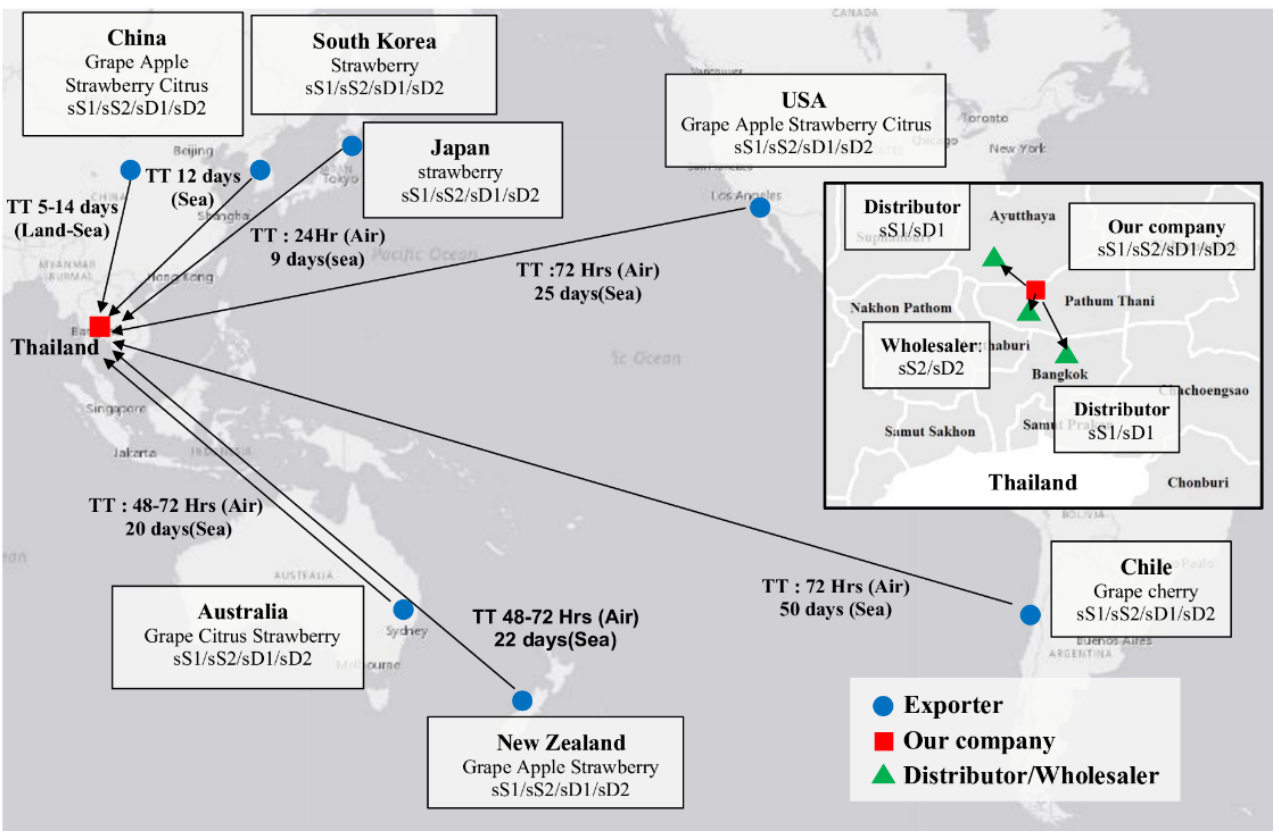

Fig. 4. Geographical map of the fresh fruit import supply chain

\subsection{SCOR Model Level 3 Process Element Level}

Level 3 is to define improvements from SCOR Level 2 (To-Be) by selecting processes that affected storage and warehouse management efficiency. Proper management can reduce the markdown price of excess products, reduce product loss and increase productivity as summarized in Table 2.

Table 2. Summary of current problems, causes, improvement, and metrics of the fresh fruit importer.

\begin{tabular}{|c|c|c|c|c|}
\hline Problem & Activity & Causes & Improvement & Metrics \\
\hline \multirow[t]{3}{*}{$\begin{array}{l}\text { Price } \\
\text { markdown } \\
\text { of slow- } \\
\text { moving } \\
\text { products }\end{array}$} & \multirow[t]{3}{*}{$\begin{array}{l}\text { Plan supply } \\
\text { chain (sp1) }\end{array}$} & $\begin{array}{l}\text { Lack of identification, } \\
\text { prioritization, and } \\
\text { aggregation supply } \\
\text { chain requirement } \\
\text { activities (sP1.1) }\end{array}$ & $\begin{array}{l}\text { - Demand planning } \\
\text { and forecasting } \\
\text { (bp.014) } \\
\text { - Characteristics-based } \\
\text { forecasting (BP.094) } \\
\text {-Omni-channel } \\
\text { (BP.176) }\end{array}$ & $\begin{array}{l}\text { Forecast } \\
\text { accuracy } \\
\text { (RL.3.37) }\end{array}$ \\
\hline & & $\begin{array}{l}\text { Lack of identification, } \\
\text { prioritization, and } \\
\text { aggregation of supply } \\
\text { chain resource } \\
\text { activities (sP1.2) }\end{array}$ & $\begin{array}{l}\text { - Supply Chain } \\
\text { Optimization } \\
\text { (BP.024) } \\
\text { - Safety Stock } \\
\text { Planning (BP.085) }\end{array}$ & $\begin{array}{l}\text { Inventory days } \\
\text { of supply } \\
\text { (AM.2.2) }\end{array}$ \\
\hline & & $\begin{array}{l}\text { Lack of balancing } \\
\text { supply chain } \\
\text { resources with } \mathrm{SC} \\
\text { requirements }(\mathrm{SP} 1.3 \text { ) }\end{array}$ & $\begin{array}{l}\text { - Baseline Inventory } \\
\text { Monitoring (BP.007) } \\
{[16]}\end{array}$ & $\begin{array}{l}\text { Fill Rate } \\
\text { (RL.3.36) }\end{array}$ \\
\hline $\begin{array}{l}\text { Food loss } \\
\text { and low } \\
\text { productivity }\end{array}$ & $\begin{array}{c}\text { Source } \\
\text { stocked } \\
\text { product (ss1) }\end{array}$ & $\begin{array}{l}\text { Lack of standard } \\
\text { practice in receive } \\
\text { product process } \\
(\mathrm{sS} 1.2)\end{array}$ & $\begin{array}{l}\text { - Develop a lot } \\
\text { tracking system } \\
\text { (BP.012) }[5,19] \\
\text { - Establish Standard }\end{array}$ & $\begin{array}{l}\text { \% Orders/ Lines } \\
\text { Processed } \\
\text { Complete } \\
\text { (RL.3.18) }\end{array}$ \\
\hline
\end{tabular}




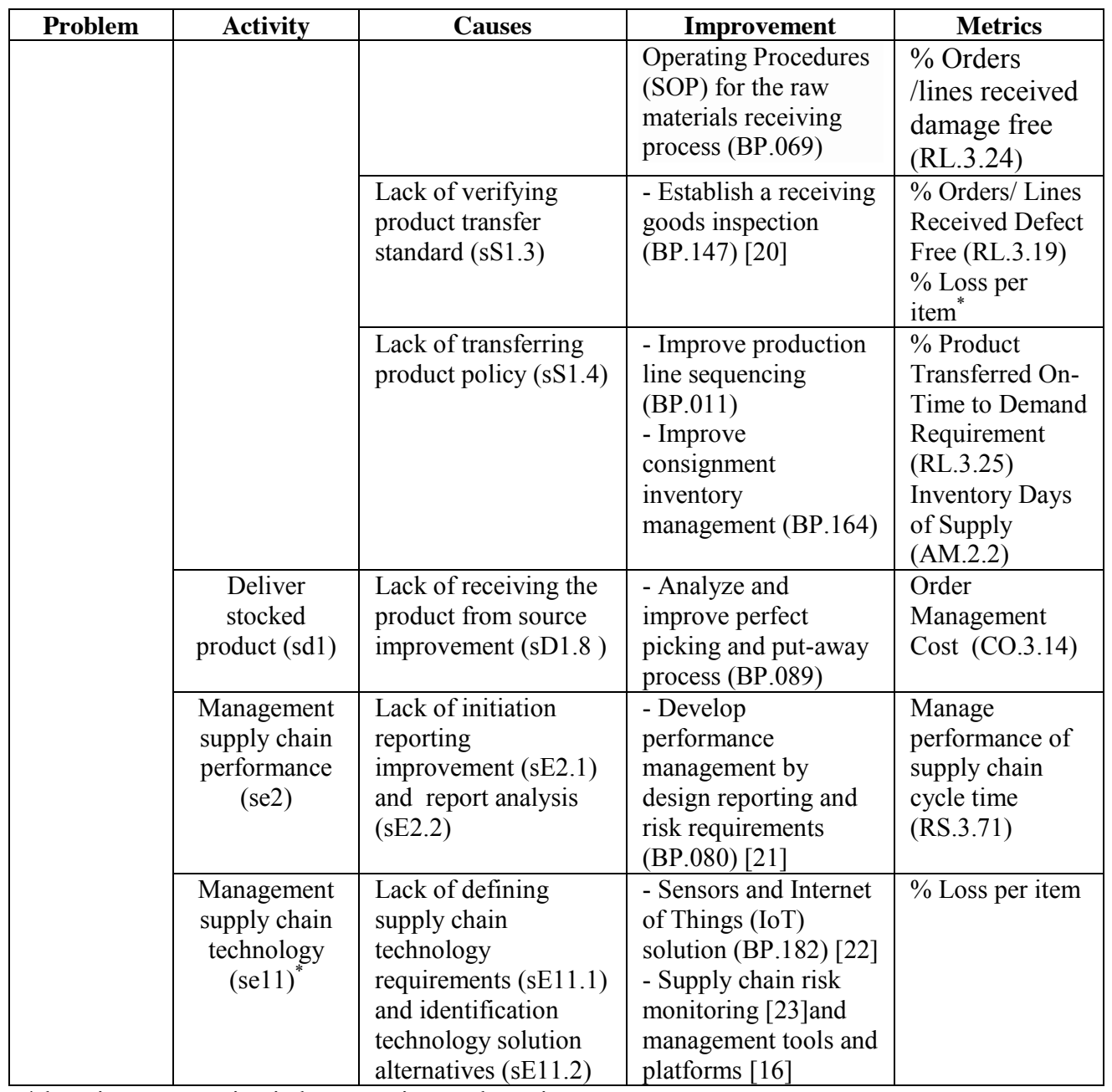

*there is no suggestion in best practices and metrics.

The problems for supply chain activities and improvement are shown in Table 2. The detail is as follows

1) Price markdown of slow-moving products occurring in plan supply chain activities caused by lack of analysis and identification of importance in the planning process not only customer demand analysis but also procurement activities-especially the lack of analysis and historical data to balance supply chain resources with whole chain requirements. The improvement approach consists of four standard practices: demand planning and forecasting, product classification and analysis characteristics-based forecasting, online marketing development, analysis of safety stock planning and inventory monitoring, and one best practice is supply chain optimization. The assessment metrics are focused on two aspects: reliability criteria consist of forecast accuracy and fills rate-furthermore, asset management efficiency criteria regarding inventory days of supply.

2) Food loss and low productivity are significant problems for the entire supply chain. It involves four activities: source stocked product, deliver stocked product, management supply chain technology, and management supply chain performance. The main cause is the lack of standard practices in receive products, processes and lack of scientific principles in verifying product transfer standards and transferring product policy. Therefore, the 
company should develope guidelines of nine practices, namely six standard practices: development of tracking systems for collecting product temperature data, defining standard operating procedures (SOPs) in the receiving process, developing scientific methods for product inspection such as product colour and core temperature, selecting line sequencing in transfer products, optimizing warehouse management so as to reduce the time and effort such as picking and storage, analyzing risks occurring throughout the supply chain and monitoring, and ultimately choosing the right technology such as real time sensors for measurement and reporting temperature using Internet of Things (IoT) solutions. The assessment metrics are divided into four aspects: 1) Reliability: complete of orders per lines processed and per received defect-free, $\%$ orders per lines received damage free, and product transferred on-time to customers requirement 2) Cost: the cost of order management 3) Responsiveness: cycle time performance in supply chain management 4) Asset management efficiency: inventory days of supply

\section{Conclusion}

Based on the SCOR model version 12, this study analyzed the import fresh fruit supply chain processes through the interview with business managers. This paper analyzed the SCOR model in three levels and showed "As-Is" or the current practices and suggest "ToBe" for process improvement. Currently, the importer supply chain management is based on executive experience and trust among stakeholders. Using the SCOR model can help the importer benchmark their operations, metrics, worker performance, and technology with world-class standards. The main problems were price markdown due to the overestimation of slow-moving products and food loss and low productivity due to no standard operations in receiving and distribution, lack of proper metrics to measure the supply chain performance, and lack of using proper techniques and technologies to enhance the performance of the operations in the temperature-controlled supply chain. Then, the best practices and metrics in the SCOR model were proposed to the importer to improve their operations. However, the guideline did not specific for the import fresh fruit industry. Hence, we suggested a metric such as $\%$ food loss per item to identify which product has a high chance of loss. In summary, the SCOR model is used to reference general standard supply chain operations and metrics that can help the company analyze the problems by benchmarking. By the way, users should be aware of the unique requirements of the industry's specific characteristics, such as cold chain management for the fresh fruits importers.

The researchers would like to thank the company to provide the information for this researc..

\section{References}

1. A. Bhatti, H. Akram, H. M. Basit, A. U. Khan, and S. M. Raza, Int. J. Futur. Gener. Commun. Netw. 13, 1449 (2020)

2. M. S. Rahman, Handbook of Food Preservation, 3rd ed. (CRC Press, 2020)

3. M. M. de Oliveira, A. Lago, and G. P. Dal' Magro, J. Clean. Prod. 294, (2021)

4. R. Ishangulyyev, S. Kim, and S. H. Lee, Foods 8, 1 (2019)

5. P. Bremer, Int. J. Logist. Manag. 29, 822 (2018)

6. Z. F. Ikatrinasari, N. Harianto, and E. I. Yuslistyari, Uncertain Supply Chain Manag. 8, 845 (2020) 
7. F. Lestari, K. Ismail, A. B. A. Hamid, and W. Sutopo, IEEE Int. Conf. Ind. Eng. Eng. Manag. 919 (2014)

8. APICS, Supply Chain Operations Reference Model SCOR Version 12.0 (Chicago, 2017)

9. G. E. Delipinar and B. Kocaoglu, Procedia - Soc. Behav. Sci. 229, 398 (2016)

10. N. Nurhasanah, in 2016 2nd Int. Conf. Ind. Mech. Electr. Chem. Eng. (IEEE, 2016),

11. H. Y. Sastra, P. D. Sentia, D. Asmadi, and M. Afifah, IOP Conf. Ser. Mater. Sci. Eng. 673, (2019)

12. D. Wahyuni, A. H. Nasution, I. Budiman, and N. Arfidhila, in J. Phys. Conf. Ser. Pap. (2020)

13. L. Hammadi, E. Souza de Cursi, V. Stefan Barbu, A. Ait Ouahman, and A. Ibourk, World Cust. J. 12, 95 (2018)

14. S. A. Teng, C. J. Chao, and M. N. Teng, in 2019 IEEE 6th Int. Conf. Ind. Eng. Appl. ICIEA 2019 (IEEE, 2019)

15. E. Kusrini, Q. Qurtubi, and N. H. Fathoni, J. Adv. Manag. Sci. 6, 218 (2018)

16. A. N. Waaly, A. Y. Ridwan, and M. D. Akbar, in MATEC Web Conf. (2018)

17. E. Kusrini, M. A. B. Rifai, and S. Miranda, in IOP Conf. Ser. Mater. Sci. Eng. (2019)

18. H. Maizi, H. Y. Sastra, and Arhami, in IOP Conf. Ser. Mater. Sci. Eng. (2020)

19. Y. Prasertwattanakul and P. Ongkunaruk, Int. Food Res. J. 25, 481 (2018)

20. O. Laguerre, H. M. Hoang, and D. Flick, Trends Food Sci. Technol. 29, 87 (2013)

21. B. Sundarakani, H. Abdul Razzak, and S. Manikandan, Int. J. Logist. Res. Appl. 21, 481 (2018)

22. N. Ndraha, H. I. Hsiao, J. Vlajic, M. F. Yang, and H. T. V. Lin, Food Control 89, 12 (2018)

23. F. Ouzayd, H. Mansouri, M. Tamir, R. Chiheb, and Z. Benhouma, Int. J. Adv.

Comput. Sci. Appl. 9, 433 (2018) 